Kansas State University Libraries

New Prairie Press

\title{
ANALYSIS OF A TWO LACTATION TARGET ANIMAL SAFETY STUDY OF SOMIDOBOVE SUSTAINED RELEASE INJECTION IN MULTIPAROUS DAIRY COWS
}

\author{
L. V. Tonkinson \\ R. P. Basson \\ R. K. McGuffey
}

A. Deldar

L. Fisher

See next page for additional authors

Follow this and additional works at: https://newprairiepress.org/agstatconference

Part of the Agriculture Commons, and the Applied Statistics Commons

\section{(c) (†) $\ominus$}

This work is licensed under a Creative Commons Attribution-Noncommercial-No Derivative Works 4.0 License.

\section{Recommended Citation}

Tonkinson, L. V.; Basson, R. P.; McGuffey, R. K.; Deldar, A.; and Fisher, L. (1989). "ANALYSIS OF A TWO LACTATION TARGET ANIMAL SAFETY STUDY OF SOMIDOBOVE SUSTAINED RELEASE INJECTION IN MULTIPAROUS DAIRY COWS," Conference on Applied Statistics in Agriculture. https://doi.org/10.4148/ 2475-7772.1450

This is brought to you for free and open access by the Conferences at New Prairie Press. It has been accepted for inclusion in Conference on Applied Statistics in Agriculture by an authorized administrator of New Prairie Press. For more information, please contact cads@k-state.edu. 


\section{Author Information}

L. V. Tonkinson, R. P. Basson, R. K. McGuffey, A. Deldar, and L. Fisher 


\section{ANALYSIS OF A TWO LACTATION TARGET ANIMAL SAFETY STUDY OF SOMIDOBOVE SUSTAINED RELEASE INJECTION IN MUITIPAROUS DAIRY COWS}

L. V. Tonkinson, Ph.D.; R. P. Basson, Ph.D.;

R. K. McGuffey, Ph.D.; A. Deldar, DVM, Ph.D.;

L. Fisher, DVM, Ph.D.

Lilly Research Laboratories

Greenfield, IN 46140

\section{Abstract}

An overview is given of the primary basis for the scientific inference that somidobove sustained release injection is safe for multiparous dairy cows. The process of analysis and interpretation of the voluminous data collected from a target animal safety study which started with 28 cows and lasted two lactations is described. This was a repeated measures study with most of 60 variables being measured or summarized every 28 days resulting in approximately 1500 measurements per cow. The statistical analysis was designed to screen the variables for biological change caused by treatment and consisted of a univariate analysis of variance for repeated measures data both within a lactation and across two lactations. Graphs of least squares means with error bounds and p-value plots of ANOVA p-values helped communicate statistical findings. A cross disciplinary approach interpreted analyses and arrived at inferences.

Key Words: repeated measures, p-value plots

\section{INTRODUCTION}

Obtaining Food and Drug Administration approval to sell a new product to U.S. dairymen to increase efficiency of milk production requires, inter alia, that its use be shown to be safe to dairy cows. A key element in the process of demonstrating safety of an animal drug is a safety study in the species for which the product is intended to be used. Target animal safety studies (TASS) are usually designed such that three groups of animals treated with the drug at $1 X, 3 X$, and $5 X$ the intended use level are compared to an untreated control group. The intent is to determine whether the efficacious, recommended use level (1X) causes adverse effects. The 5X level should identify variables of greatest sensitivity to toxicologic impact and allow an estimate of the magnitude of the toxicity. The $3 X$ level improves the chances of achieving both objectives.

\section{MATERIAL AND METHODS}

In order to provide an in-depth safety profile for somidobove, a form of bovine somatotropin produced by recombinant DNA technology, a TASS was conducted with the product on 28 multiparous dairy cattle under simulated field use conditions during two consecutive lactations. Individual animal (quantitative) response observations were determined for 60 variables (Table 1) at frequencies that varied from twice daily (yield milk) to once every three months (milk phosphorus concentration). These attributes together with the biologists' preference for univariate tests at each sampling in time, over multivariate type analyses, made summarization and analysis a challenge. 
The 28 animals were distributed across treatment classes as follows:

\begin{tabular}{lcccccc} 
& \multicolumn{4}{c}{ Somidobove per 28 days } & \\
\cline { 2 - 6 } Lactation & 0 & $960 \mathrm{mg}$ & $2880 \mathrm{mg}$ & $4800 \mathrm{mg}$ & $\begin{array}{c}\text { Total } \\
\text { cows }\end{array}$ \\
\hline lst & 7 & 7 & 7 & 7 & 28 \\
2nd & 7 & 5 & 3 & 7 & 22
\end{tabular}

Dropouts from multilactation dairy trials are unavoidable; this complicated analysis.

To focus attention on variables affected by treatment, to avoid missing potential problems, and yet to keep analysis understandable, we utilized the two types of analyses -- within lactation and lactations combined -described below.

Within Lactations

Somidobove was injected subcutaneously every 28 days for 10 consecutive treatments; 36 variables were measured in blood samples collected every 28 days. For a large majority of the variables, summarization of the data by 28-day period means allowed treatment effects within a single lactation to be evaluated.

To identify variables most sensitive to somidobove over time within each lactation, the following statistical screen devised in consultation with the FDA Center for Veterinary Medicine personnel was implemented. Forty variables either observed every 28 days, or summarized on a 28-day basis, were analyzed by the following model:

$\begin{array}{lcr} & \begin{array}{c}\text { lactation } \\ \text { Source }\end{array} & \begin{array}{r}\text { lactat } \\ \text { df }\end{array} \\ \text { Treatment } & & \\ \text { Cows (treatment) } & 3 & 3 \\ \text { Period } & 24 & 19 \\ \text { Treatment x period } & 9 & 9 \\ \text { Error } & 27 & 27 \\ & 205 & 163\end{array}$

This analysis was appropriately modified for variables observed every three months within each lactation.

Furthermore, treatment $x$ period effect was partitioned into three component effects:

- control vs $960 \mathrm{mg}$ x period

- control vs $2880 \mathrm{mg} \times$ period

- control vs $4800 \mathrm{mg} x$ period

In this model, period was a repeated measures effect and treatment $x$ period effect reflected changes that occur in treatment effects over time during 
the lactation. Concatenation of period mean values over two lactations onto one graph provided an effective way to visually demonstrate the exquisite sensitivity of this screen (Figure 1).

Lactations Combined

To satisfy the second objective of determining long-term administration (two lactation) effects, all observations for a variable during each lactation were averaged into a single value. Lactation summary values were the observations employed in this statistical analysis to estimate response to treatments.

Treatments were assigned to animals only once, making the individual animal the experimental unit. The statistical model for this overall study analysis was:

\begin{tabular}{lr} 
Source & df \\
\cline { 3 - 3 } Treatment & 3 \\
Cows(treatment) & 24 \\
Lactation & 1 \\
Treatment x lactation & 3 \\
Error & 18
\end{tabular}

Lactation was a repeated measures effect in the statistical model. The treatment $x$ lactation interaction effect reflected changes that may occur in treatment effect from the first to the second lactation. Cows (treatment) was the error term for testing treatment effects and contrasts in this model.

In this TASS sixty quantitative variables (Table 1 ) required analysis. Fisher (1937) discussed analysis of variance (ANOVA) in the context of one or perhaps only a few variables. Consequently, to avoid being misled by random chance variation, a global view of the study was needed. To do this, a p-value plot of all variables collected, a technique exemplified by Schweder and Spjotvoll (1982), was used. Theory says that in a p-value plot of ANOVA p-values all points corresponding to true null hypotheses should approximate a straight line, while those representing false null hypotheses should deviate from the line. The line can, therefore, be used to estimate the number of true null hypotheses. Two biologically similar measures like $\mathrm{MCH}$ and $\mathrm{MCV}$ are statistically independent enough in realization, i.e. measurement error, for the approach to be practical in a multivariable TASS. This approach was applied separately first to test treatment $x$ lactation (Figure 5), and also to all three contrasts of primary interest (control vs $960 \mathrm{mg}$ group, control vs $2880 \mathrm{mg}$ group, and control vs $4800 \mathrm{mg}$ group).

\section{RESULTS AND DISCUSSION}

Within Lactations

A variable adversely affected by somidobove over time would exhibit a profile not parallel to that of the control. A sensitive indicator of this non-parallelism (i.e. variables that increase as well as those that 
decrease compared to control) was provided by the treatment contrast by period interaction. A significant contrast $x$ period interaction selected variables in need of biological evaluation; if significance occurred for any variable for any of these interactions for either first or second lactation, then graphs of treatment $x$ period least squares means \pm standard error for the affected variable were made to assist in a biological evaluation of the finding. An example analysis of variance with treatment contrast by period interactions highlighted is in Table 2. A summary of contrast p-values is shown in Table 3; graphs for a selected few variables appear in Figures $1-4$.

Making a complete graphic necessitated 'pretreatment' or covariate least squares mean values be plotted as period/month 0 (beginning of lactation 1) and 15 (beginning of lactation 2). These means \pm standard errors were obtained by reapplying a similar analysis to a dataset restricted to consist of observations obtained at these times.

Statistical science is a powerful aid to inference not a panacea. The error terms used in the above statistical screen are auto-correlated ones, known to be too small, and thus prone to give false signals that something other than random variability has influenced the result. They have 205 and 163 degrees of freedom in lactation 1 and 2, respectively, and are compiled from repeated measures over time from the same individual; "statistically" independent they may be, "biologically" independent they are not. Greenhouse and Geisser (1959) suggested making the test with degrees of freedom divided by the number of periods less one to reduce spurious significance. Conversely, Huynh and Feldt (1970) showed these tests were valid F-statistics (with a df multiplier $(\varepsilon$ ) equal to one) if, and only if, all possible time differences $x_{i}-x_{j}(i \neq j)$ are equally variable. Homeostatic TASS variables over time appear to be a tailor-made example requiring no $\varepsilon$ correction to be made.

A 'significant' ( $p<.002$ ) control vs $2880 \mathrm{mg} x$ period value for aspartate transaminase (AST), in lactation 1 (Tables 2 and 3, Figure 1) draws attention to the different amount of white space between the two relevant bounds over periods. In particular, none prior to period 4, a noticeable amount for one period, and then a small amount for the remainder of lactation 1. Failure of the finding to repeat in lactation two or for the $4800 \mathrm{mg}$ contrast to reinforce the finding make it less than compelling.

Borderline significance occurred on two occasions for AlbuminfGlobulin $(A / G)$ ratio for control vs $2880 \mathrm{mg} x$ period (Table 3, Figure 2). Evidently, the test was highly sensitive to idiosyncrasy in the crossingover patterns of the two bounds. The finding was not repeated for $4800 \mathrm{mg}$ despite an equally disparate set of bounds; and the more reason why borderline significance $(\mathrm{p} \leqq .05)$ on a single occasion is shaky statistical grounds for a claim that something other than random variability has influenced the result.

Systematic scrutiny of the plots of the 19 variables that had at least one significant contrast interaction listed in Table 3 identify only somidobove level in the blood (BST) and the erythrocytic variables to be showing more than random variation during somidobove treatment. Somidobove level in 
blood tended to increase with time during the first lactation but not during the second lactation.

Erythrocytic Variables: Contrasts of control vs. $2880 \mathrm{X}$ period and control vs. $4800 \mathrm{X}$ period were consistently at or below a probability of 0.01 for mean corpuscular volume (MCV) and mean corpuscular hemoglobin (MCH) in both Lactations 1 and 2 (Table 1). In addition, contrasts of control vs $4800 \mathrm{X}$ period for erythrocyte count were significant $(P=.05)$ in Lactation 2 only (Table 3). None of the six contrasts is significant for either packed cell volume (PCV) or hemoglobin concentration (HGB).

Changes in erythrocytic variables are generally interrelated. Therefore, any changes in erythrocyte count, hemoglobin concentration and PCV should affect the $\mathrm{MCV}$ and $\mathrm{MCH}$ values as well. But in this interaction screen confidence bounds for MCV (Figure 3) and $\mathrm{MCH}$ (Figure 4) were less parallel over the lactation than the corresponding ones for PCV and HGB.

The slight changes in $\mathrm{MCV}$ and $\mathrm{MCH}$ in the absences of corresponding changes in other erythrocytic variables may be explained by the fact that long-term intramuscular or subcutaneous administration of a compound often causes minor inflammatory reactions at the injection sites. Observation of dose-related minor irritation at the injection sites in this study was the case. It is known that any inflammatory reaction will perturb erythropoiesis resulting in production of red cells with reduced $M C V$ and $M C H$ (Jain, 1968). Fluctuation in erythrocytic variables is reported to be common in bovine species during the first few years of life before becoming stabilized (Jain, 1986). High producing cows often have lower hemoglobin concentration than low producing cows (Whitlock et al., 1974).

While erythrocyte count, hemoglobin concentration and PCV, like in the figures for $\mathrm{MCV}$ and $\mathrm{MCH}$, tend to be reduced slightly, sometimes significantly, in a dose related fashion with somidobove dosage, all mean values are well within the normal ranges for these variables.

Lactations Combined

A sample of analysis of variance for data with lactations combined is in Table 4. The variable is calving interval and $p$-values for treatment $x$ lactation, control vs $4800 \mathrm{mg}$, and control vs $960 \mathrm{mg}$ appear in Figures 5, 6, and 7 , respectively.

Lactation $x$ Somidobove Level: Figure 5 shows a p-value plot of all tests of Treatment $x$ Lactation effect for multiparous cows. The plot shows excellent conformity with a "450 line plot". Such agreement indicated the experiment viewed as a whole provides no evidence that treatment effects for cows are different in the two lactations tested.

The p-value plot technique isolated easily the following situation which has a ready explanation for why it is "unusual". Mean birth weights in lbs of calvings by lactation and multiplicity were: 


\begin{tabular}{|c|c|c|c|c|}
\hline Lactation & Control & $960 \mathrm{mg}$ & $2880 \mathrm{mg}$ & $4880 \mathrm{mg}$ \\
\hline & \multicolumn{4}{|c|}{ Single Birth Calvings } \\
\hline 1 & $\begin{array}{c}106.7 \\
(6)\end{array}$ & $\begin{array}{r}97.6 \\
(5)\end{array}$ & $\begin{array}{l}103.3 \\
(3)\end{array}$ & $\begin{array}{r}92.0 \\
(6)\end{array}$ \\
\hline \multirow[t]{2}{*}{2} & $\begin{array}{l}105.4 \\
(5)\end{array}$ & $\begin{array}{r}109.8 \\
(4)\end{array}$ & $\begin{array}{c}108.0 \\
(1)\end{array}$ & $\begin{array}{r}60.0 \\
(1)\end{array}$ \\
\hline & \multicolumn{4}{|c|}{ Twin Birth Calvings } \\
\hline 1 & $\begin{array}{l}72.0 \\
(1)\end{array}$ & & & $\begin{array}{r}73.0 \\
(2)\end{array}$ \\
\hline 2 & & & & $\begin{array}{r}67.0 \\
(4)\end{array}$ \\
\hline
\end{tabular}

Somidobove at $960 \mathrm{mg}$ appears to have no detrimental effect on calf weight. It may appear prudent to draw the inference from this table that the 4800 mg level begins to impact calf weight in the second lactation. An alternative simple explanation is by chance more twins were in the $4800 \mathrm{mg}$ group; all that is being detected is that twins are smaller and weigh less than calves of single births.

Control vs $4800 \mathrm{mg}$ somidobove: Figure 6 shows the classic "two intersecting lines" pattern; the intersection point provides a good cut-point or signal of variables affected by the $4800 \mathrm{mg}$ somidobove level. Indeed scientific evaluation needs to focus only on variables listed above where two lines intersect (albumin globulin ratio, AG RA); only they exhibit contrast probabilities that are beyond chance expectation under the null hypothesis.

Control vs $960 \mathrm{mg}$ somidobove: The two-lactation average milk production increase estimate due to $960 \mathrm{mg}$ is a respectable $2.43 \mathrm{~kg} /$ day (P level = .22); small sample size and an imbalanced sample have likely contributed to the non-significance of this result. Figure 7 shows the p-value plot for control vs $960 \mathrm{mg}$ somidobove. This plot shows $960 \mathrm{mg}$ somidobove to be without effect on the 60 variables tested.

IV. CONCLUSIONS

The auto-correlated error used to signal treatment effects over time in the within-lactation analyses gave many false positive signals; the plots of means over time \pm standard error bounds, p-value magnitude and biological knowledge easily screened out such 'spurious' significances.

This small two lactation study confirms that somidobove increases fat corrected milk and milk yield. In cows, the $4800 \mathrm{mg}$ level produces yield effects in the 4-5 kg/day range; the quality of milk was unaffected. Increased milk production evidently stimulates a corresponding small 
increase in dry matter intake. When this is not sufficient to sustain all the increased production, body-fat stores are utilized. Rate of weight gain and average body weight all reflect this self-limiting process; cows on 960 - $4800 \mathrm{mg}$ somidobove weighed about $25 \mathrm{~kg}$ less at the end of their lactations than did comparable controls.

At the highest level of somidobove (4800 $\mathrm{mg}$ ) clinical chemistry and hematology variables affected were blood urea nitrogen, total protein, globulin, albumin globulin ratio, mean corpuscular volume, thrombocytes, mean corpuscular hemoglobin, packed cell volume, hemoglobin and eosinophils. The low level ( $960 \mathrm{mg}$ ) showed no effect on these variables.

A review of all the variables which were tested in this study did not reveal any biologically significant changes that would preclude the safe use of somidobove in multiparous dairy cows.

\section{ACKNOWLEDGEMENT}

Consultation and advise of Robert J. Condon, Ph.D.; Margaret T. Roper, MS; and Richard P. Lehmann, Ph.D. of the Center for Veterinary Medicine, U.S. Food and Drug Administration is acknowledged.

\section{REFERENCES}

Fisher, R. A. (1937). "The Design of Experiments", 2nd Edition, Pg. 57. Oliver and Boyd, London.

Greenhouse, S. W. and Geisser S. (1959). On Methods in the Analysis of Profile Data. Psychometrika 24:95-112.

Huynh, H. and Feldt, L. S. (1970). Conditions Under Which Mean Square Ratios in Repeated Measurements Designs have Exact $F$ Distributions. Journal of the American Statistical Association 65:1582-1589.

Jain, N. C. 1986. Schalm's Veterinary Hematology, Jain NC, Editor, Pg. 179. Lea and Febiger, Philadelphia.

Schweder, I. and Spjotvoll, E. (1982). Plots of p-values to evaluate many tests simultaneously. Biometrika 69:493-502.

Whitlock, R. H., W. Little, and G. J. Rowlands (1974). The incidence of anemia in dairy cows in relation to season, milk yield and age. Research in Veterinary Science 16:122. 


\section{TABLE 1. SOMIDOBOVE TARGET ANIMAL SAFETY STUDY T4UVX8516}

Variables Analyzed

$\begin{array}{ll}\text { AG_RA } & \text { Albumin globulin ratio } \\ \text { ALB } & \text { Albumin } \\ \text { ALP } & \text { Alkaline phosphatase } \\ \text { AST } & \text { Aspartate transaminase } \\ \text { BND } & \text { Bands } \\ \text { BUN } & \text { Blood urea nitrogen } \\ \text { CA } & \text { Calcium } \\ \text { CIIOL } & \text { Cholesterol } \\ \text { Q. } & \text { Chloride } \\ \text { CREAT } & \text { Creatinine } \\ \text { GLOB } & \text { Globulin } \\ \text { QLU } & \text { Glucose } \\ \text { I_PHO } & \text { Inorganic phosphorus } \\ \text { K } & \text { Potassium } \\ \text { NA } & \text { Sodium } \\ \text { SDHI } & \text { Sorbitol dehydrogenase } \\ \text { SZINC } & \text { Serum zinc } \\ \text { T_BIL } & \text { Total bilirubin } \\ \text { T_Pro } & \text { Total protein } \\ \text { TRIGL } & \text { Triglycerides } \\ \text { BASO } & \text { Basophils } \\ \text { EOS } & \text { Eosinophils } \\ \text { HRYS } & \text { Erythrocytes } \\ \text { IGB } & \text { Hemoglobin } \\ \text { LEUK } & \text { Leukocytes } \\ \text { LYMPII } & \text { Lymphocytes } \\ \text { MCII } & \text { Mean corpuscular hemoglobin } \\ \text { MCIIC } & \text { Mean corpuscular hemoglobin } \\ & \text { concentration } \\ \text { MCV } & \text { Mean corpuscular volume } \\ \text { MONO } & \text { Monocytes } \\ & \end{array}$

TABLE 2. ANALYSIS OF VARIANCE OF ASPARTATE TRANSAMINASE (AST) DATA FROM THE FIRST LACTATION

\begin{tabular}{|c|c|c|c|c|c|}
\hline Source & D.E & $\begin{array}{l}\text { Typ } \\
\text { Sum of }\end{array}$ & $\begin{array}{l}\text { III } \\
\text { Squares }\end{array}$ & $\mathrm{F}$ & $P$ \\
\hline Treatment & 3 & \multicolumn{2}{|c|}{2362.57} & 9.85 & 0.0001 \\
\hline Cow(Treatment) & 24 & \multicolumn{2}{|c|}{14157.57} & 7.38 & 0.0001 \\
\hline Period & 9 & \multicolumn{2}{|c|}{2708.05} & 3.76 & 0.0002 \\
\hline TreatxPeriod & 27 & \multicolumn{2}{|c|}{3673.95} & 1.70 & 0.0211 \\
\hline Error & 205 & \multicolumn{2}{|c|}{16388.35} & & \\
\hline Contrast & & D.F. & SS & $\mathrm{F}$ & $P$ \\
\hline Control vs $960 \mathrm{mg}$ & by Period & 9 & 235.49 & 0.33 & 0.9653 \\
\hline Control vs $2660 \mathrm{mg}$ & by Period & 9 & 2239.49 & 3.11 & 0.0016 \\
\hline Control vs $4800 \mathrm{~m}$ & by period & 9 & 481.48 & 0.67 & 0.7362 \\
\hline
\end{tabular}

\begin{tabular}{ll} 
NEUT & Neutrophil \\
PCV & Packed cell volume \\
TIIRMB & Thrombocytes \\
BST & Bovine somatotropin \\
INSUL & Insulin \\
T4 & Thyroxine \\
B_WT & Body weight \\
BREI & Breeding interval (days \\
& \multicolumn{1}{c}{ to first breeding) } \\
CALFII & Calf height \\
CALFL & Calf length \\
CALFW & Calf weight \\
CALVI & Calving interval \\
DAYSM & Days milked \\
DAYSO & Days open \\
DMI & Dry matter intake \\
F_EST & First estrus \\
GES_I & Gestation interval \\
MCALC & Milk calcium \\
MFAT & Milk fat \\
MLACT & Milk lactose \\
MPHOS & Milk phosphorus \\
MPROT & Milk protein \\
MTSOL & Milk total solids \\
MZINC & Milk zinc \\
NEI & Net energy intake \\
NSERV & Number of services \\
S_CEL & Somatic cells \\
WT_GA & Weight gain \\
YFCM & Yield 3.5\% fat \\
& corrected milk \\
YMILK & Yield milk \\
\multicolumn{2}{|c|}{} \\
\end{tabular}


TABLE 3. SUMMARY OF SEJECTED P-VALUES FOR CONTRAST X PERIOD INTERACTION FOR THE TEN TREATMENT PERIODS DURING EACII LACTATION

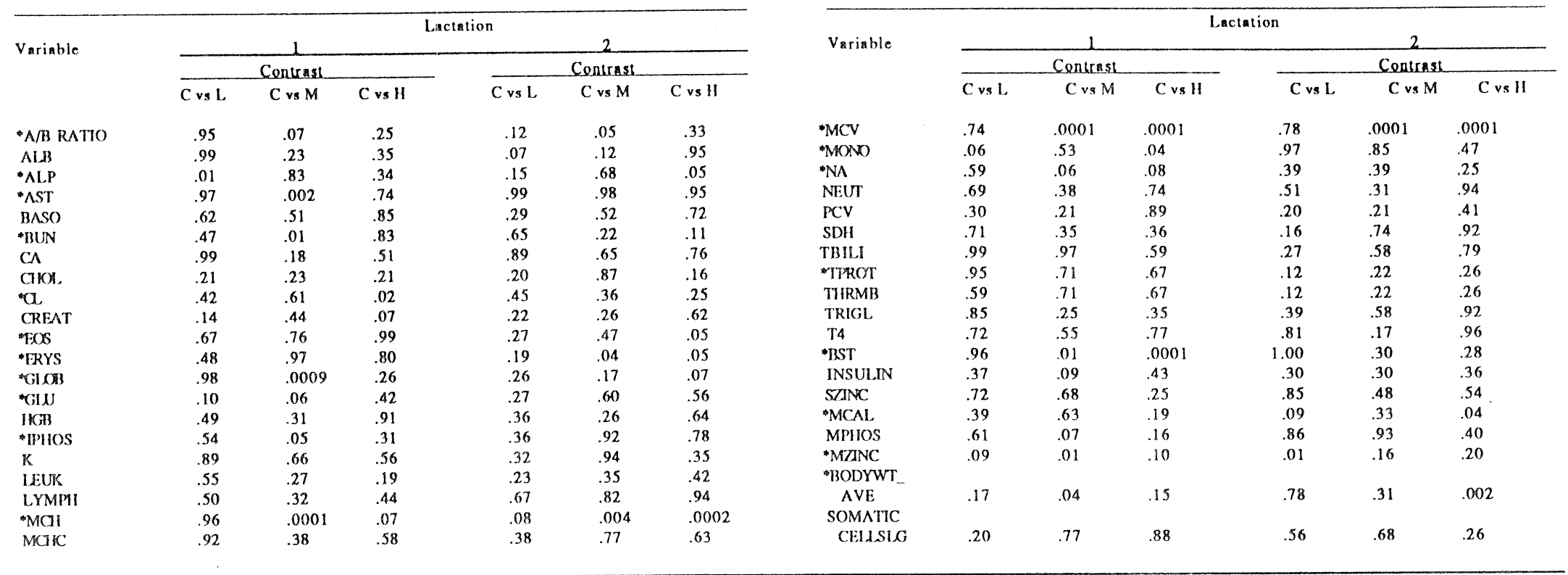

*Graphs over two lactations were made for these variables

TABLE 4. ANALYSIS OF VARIANCE OF CALVING INTERVAL DATA FOR COWS CALVING OVER BOTH LACTATIONS

\begin{tabular}{|c|c|c|c|c|}
\hline Source & D.E. & $\begin{array}{c}\text { Type III } \\
\text { Sum ol Squares }\end{array}$ & $\mathrm{E}$ & $\mathrm{p}$ \\
\hline Treatment & 3 & 4180.37 & 0.47 & 0.7107 \\
\hline $\operatorname{Cow}(\text { Treatment })^{1}$ & 19 & 62906.23 & 1.11 & 0.4382 \\
\hline Lactation & 1 & 30864.46 & 10.34 & 0.0074 \\
\hline TreatxLactation & 3 & 8563.12 & 0.96 & 0.4445 \\
\hline Error & 12 & 35800.75 & & \\
\hline Contrasts & DE. & SS & $\mathrm{F}$ & $P$ \\
\hline Control vs $960 \mathrm{mg}$ & 1 & 1565.34 & 0.47 & 0.5000 \\
\hline Control vs $2660 \mathrm{mg}$ & 1 & 1891.10 & 0.57 & 0.4591 \\
\hline Control vs $4800 \mathrm{mg}$ & 1 & 235.84 & 0.07 & 0.7924 \\
\hline
\end{tabular}

'Cow (treatment) was the error term for the contrasts. Only 19 degrees of freedom because all cows did not calve the second or third time. 
Flgure 1 Somldobove Two Lactailon Targef Animal Sarety Słudy Aspartate Transaminase (AST)
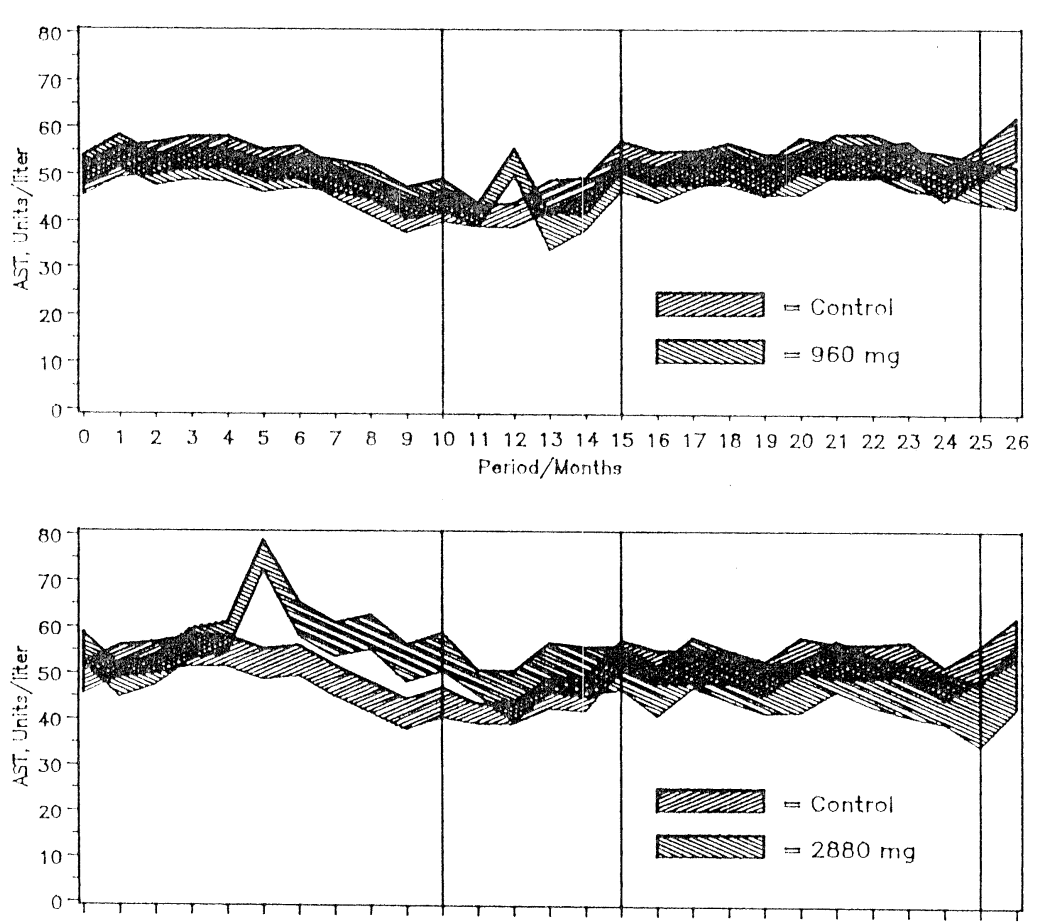

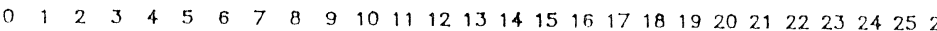
Period/Months

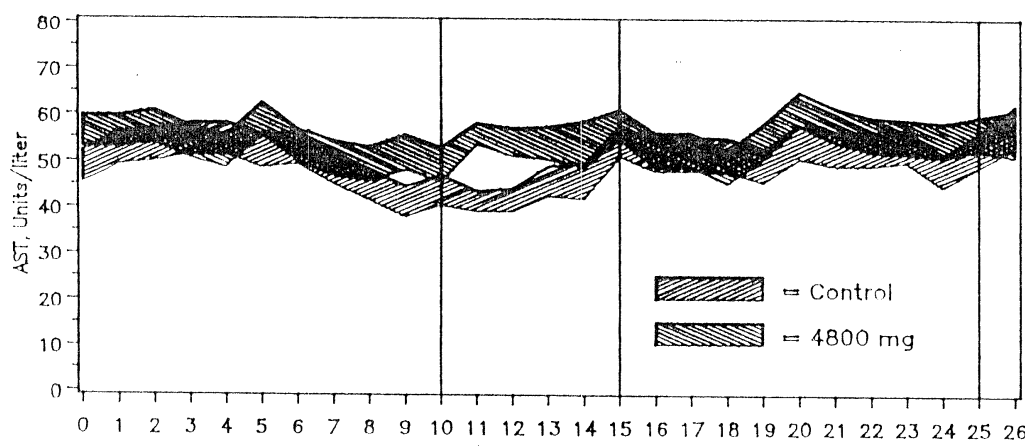
Period/Months

Bounds for the treatments are least squares means + or - STD Error.
Figure 2 Somidobova Two Lactation Target Animal Safety Study Albumin/Globulin Rałlo (A/G)

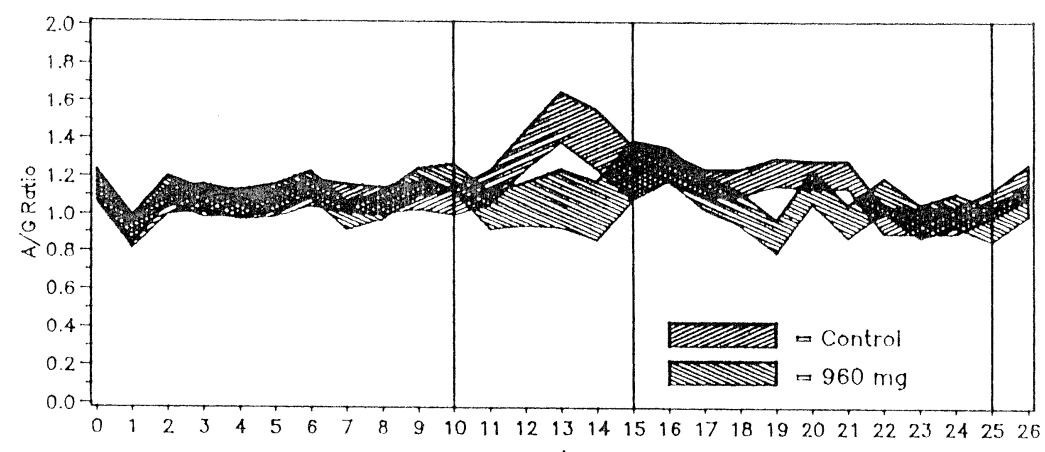

Period/Months

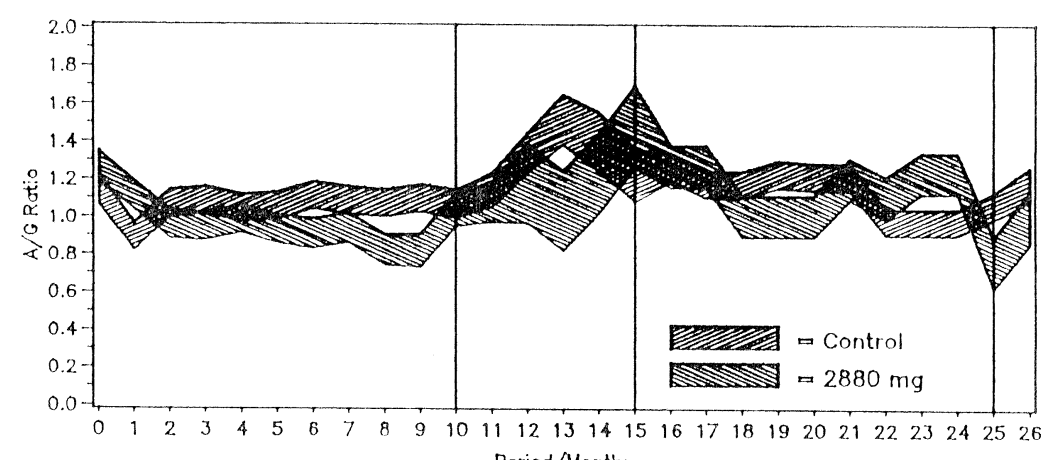
Period/Months

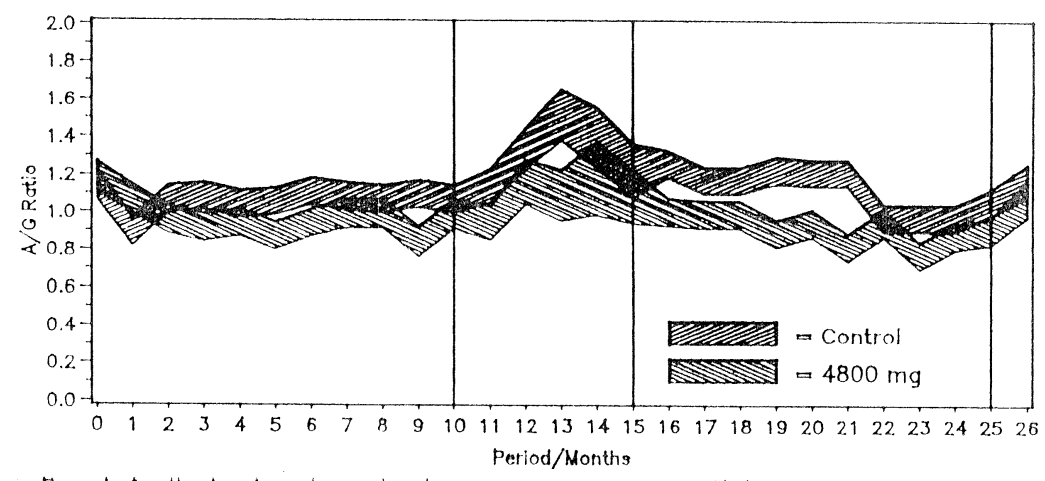

Bounds for the treatments are least squares means + or - STD Error. 
Flgure $3 \quad$ Somldobove Two Lactation Target Animal Safety Study Mean Corpuscular Volume (MCV)
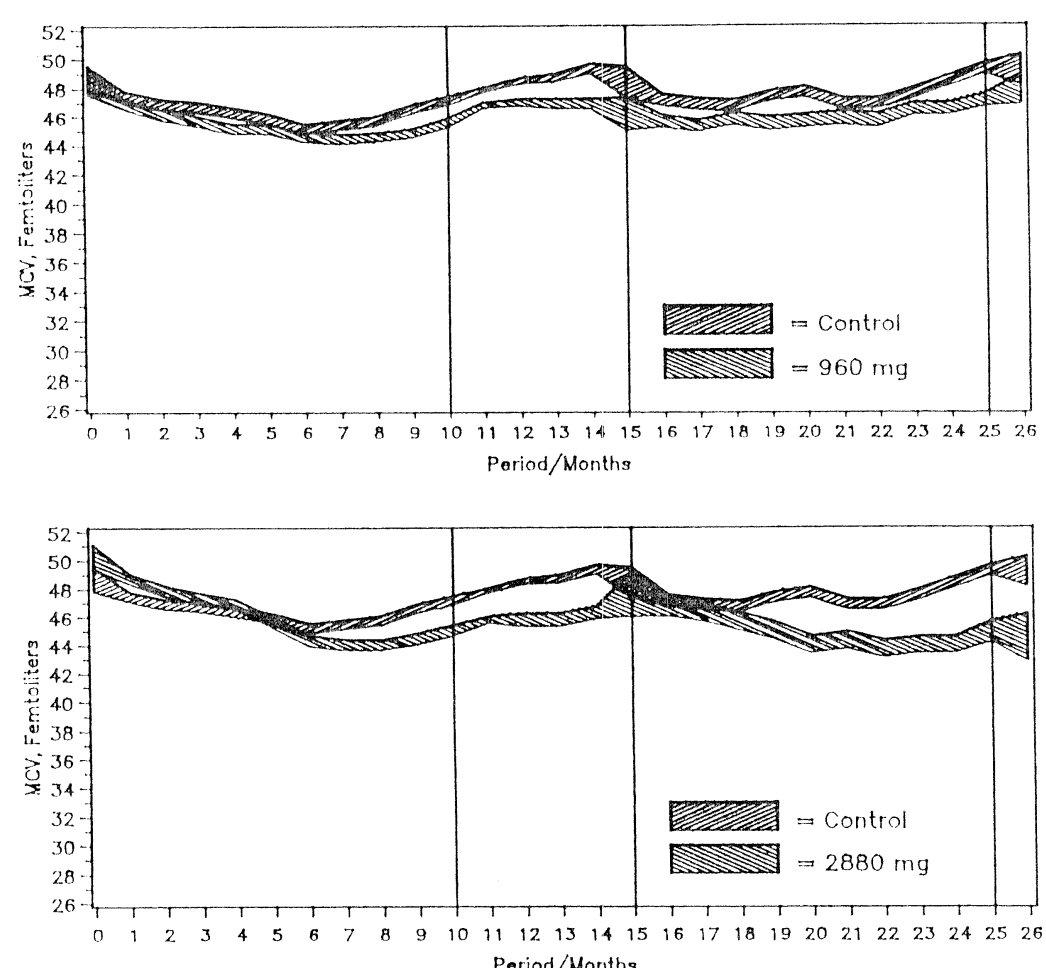
Period/Moriths

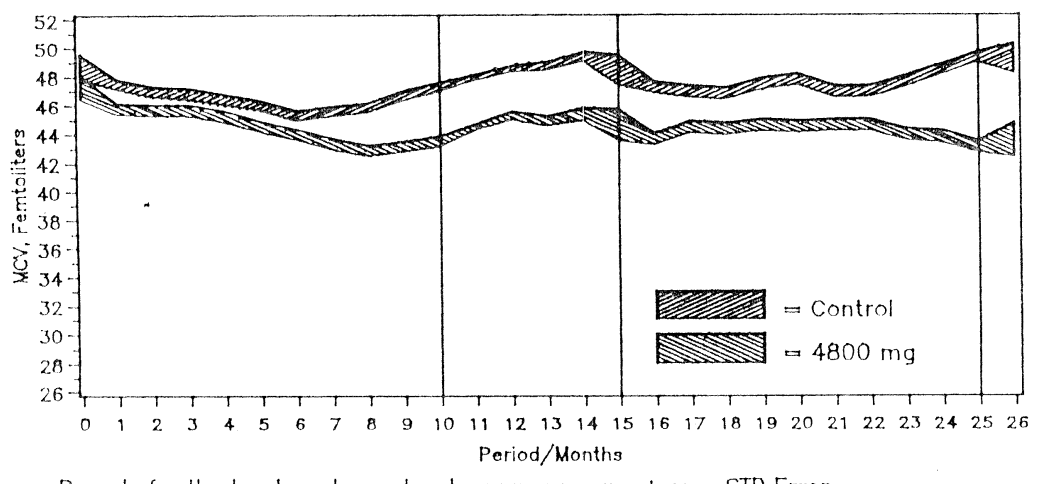

Bounds for the treatments are least squares means + or - STD Error.
Flgure 4 Somldobove Two Lactallon Targể Anlmal Safeły Słudy Mean Corpuscular Hemoglobin (MCH)
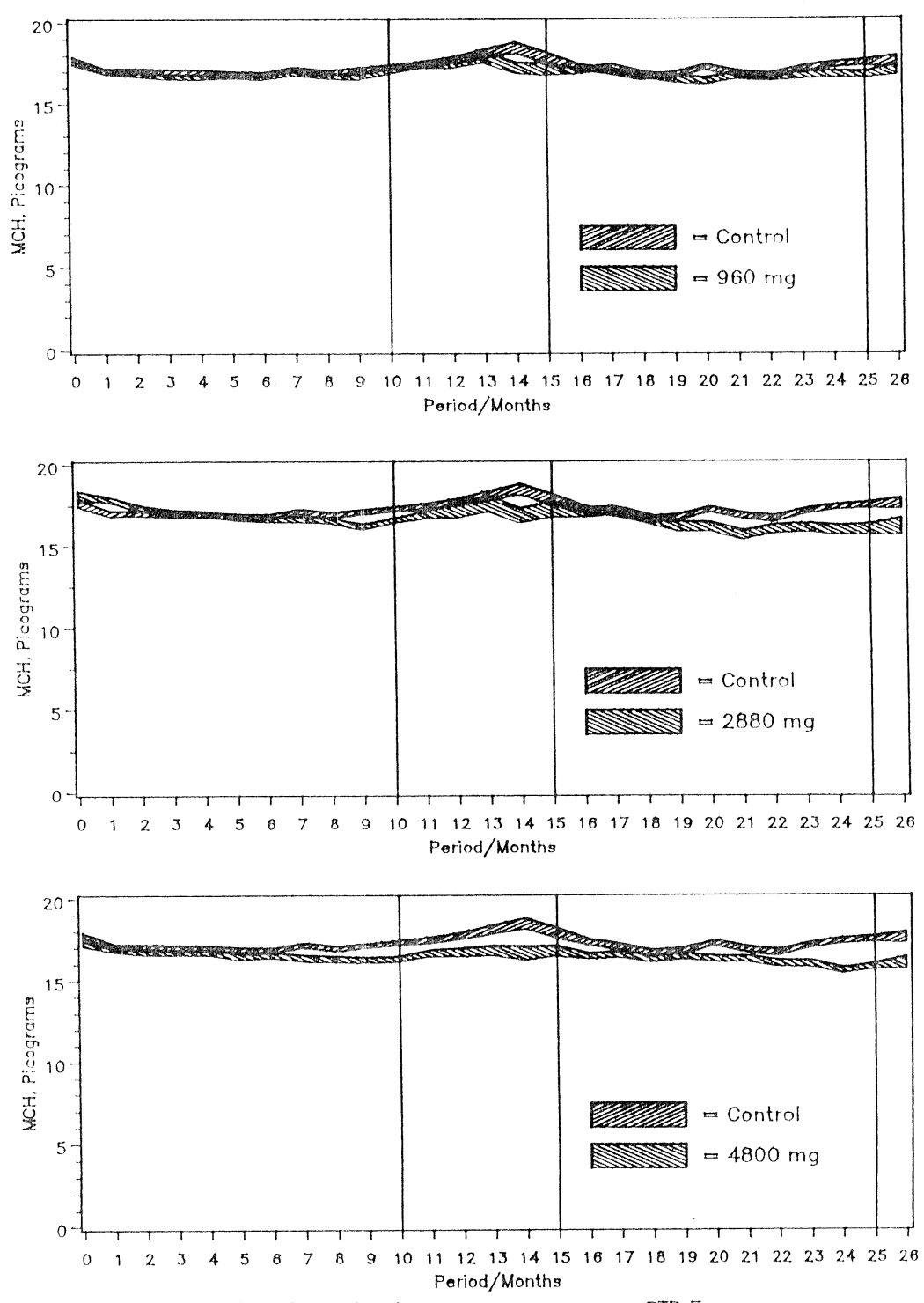

Bounds for the treatments are least squares means + or - STD Error. 
Figure 5 Distribution of Probabilities - Lactation X Somidobove Level

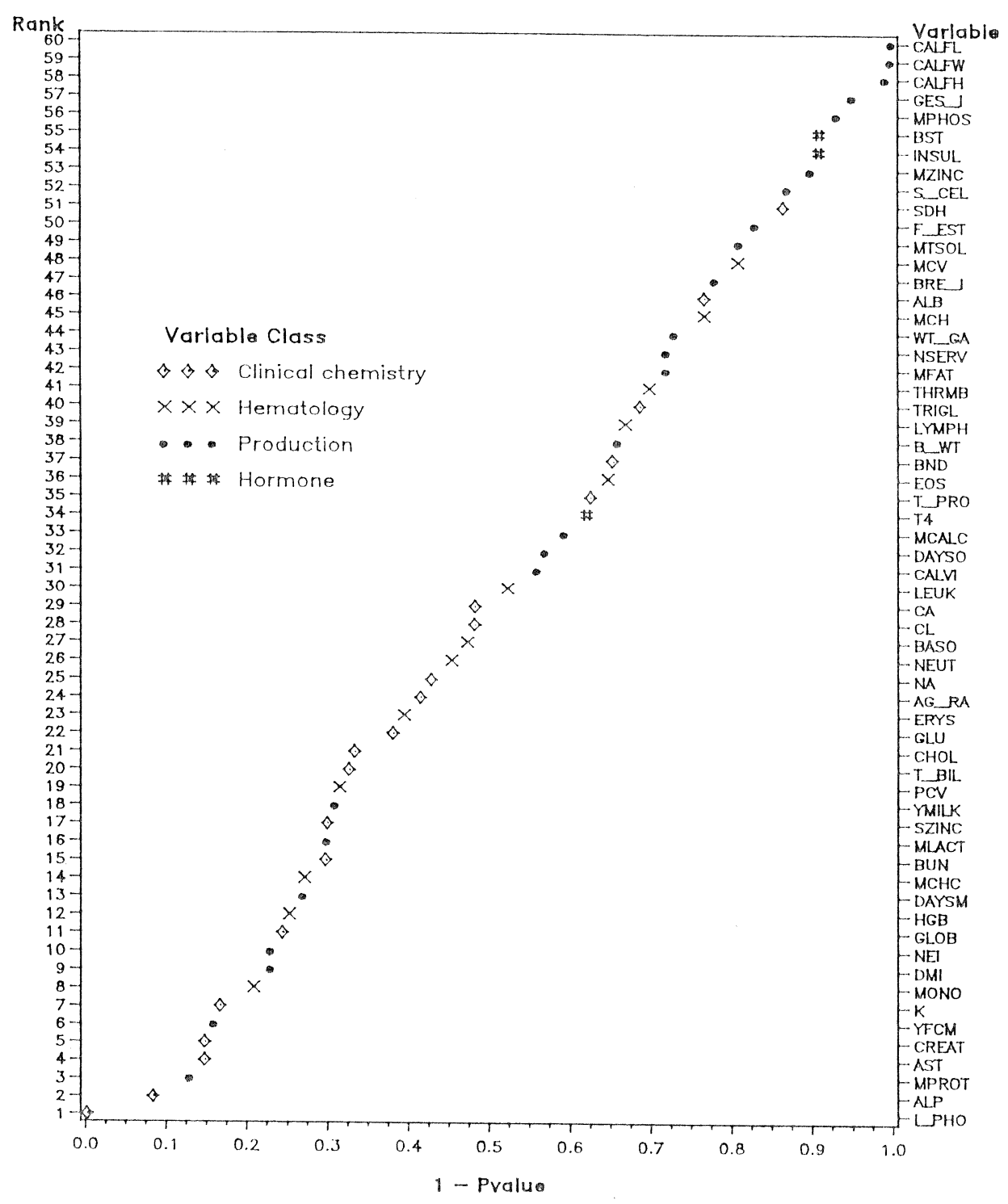


Figure 6 Distribution of Probabilities - Control vs Somidobove 4800 mg/28days

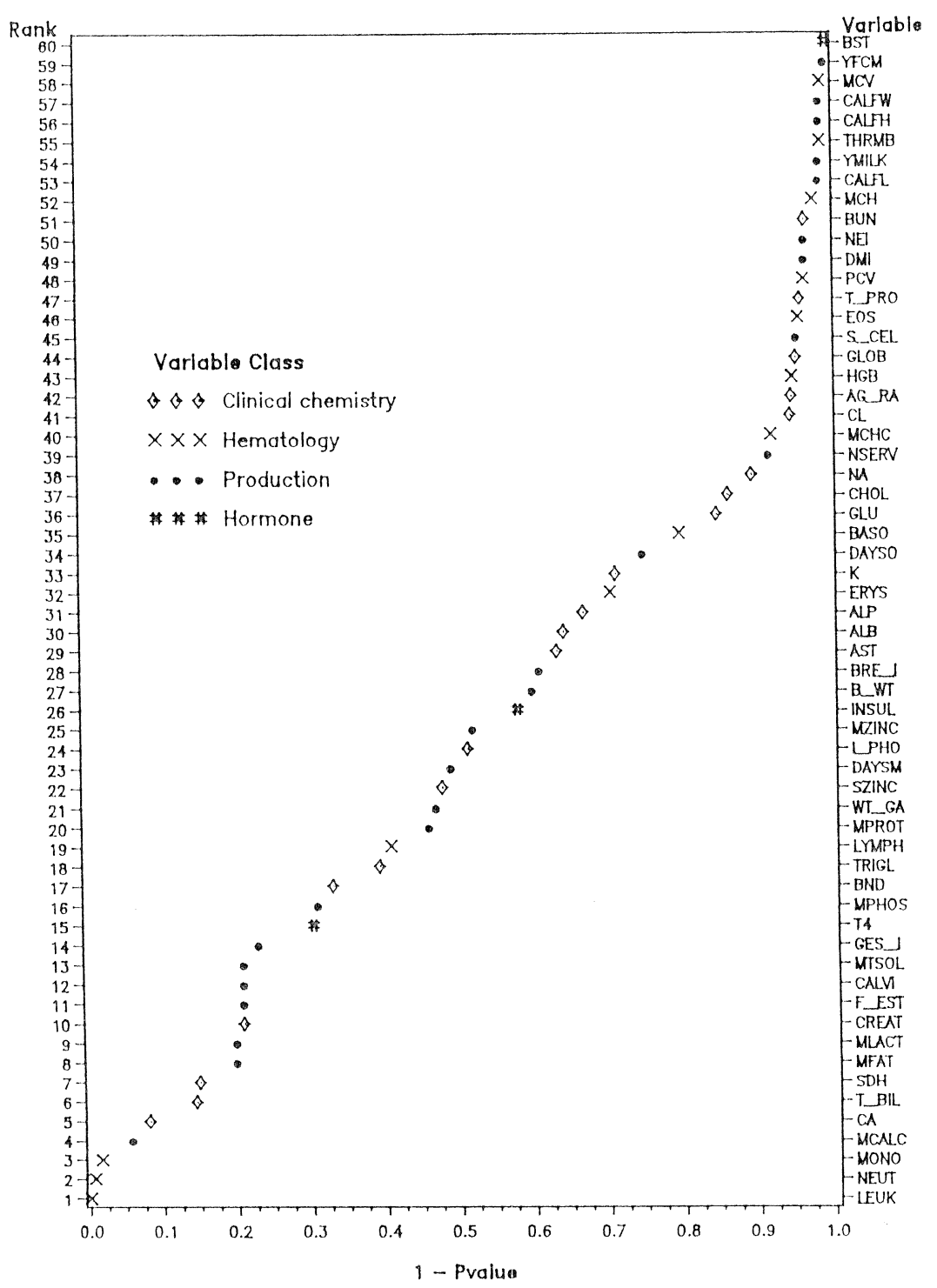

Flgure 7 Distribution of Probabilities - Control vs Somidobove 960 mg/28days

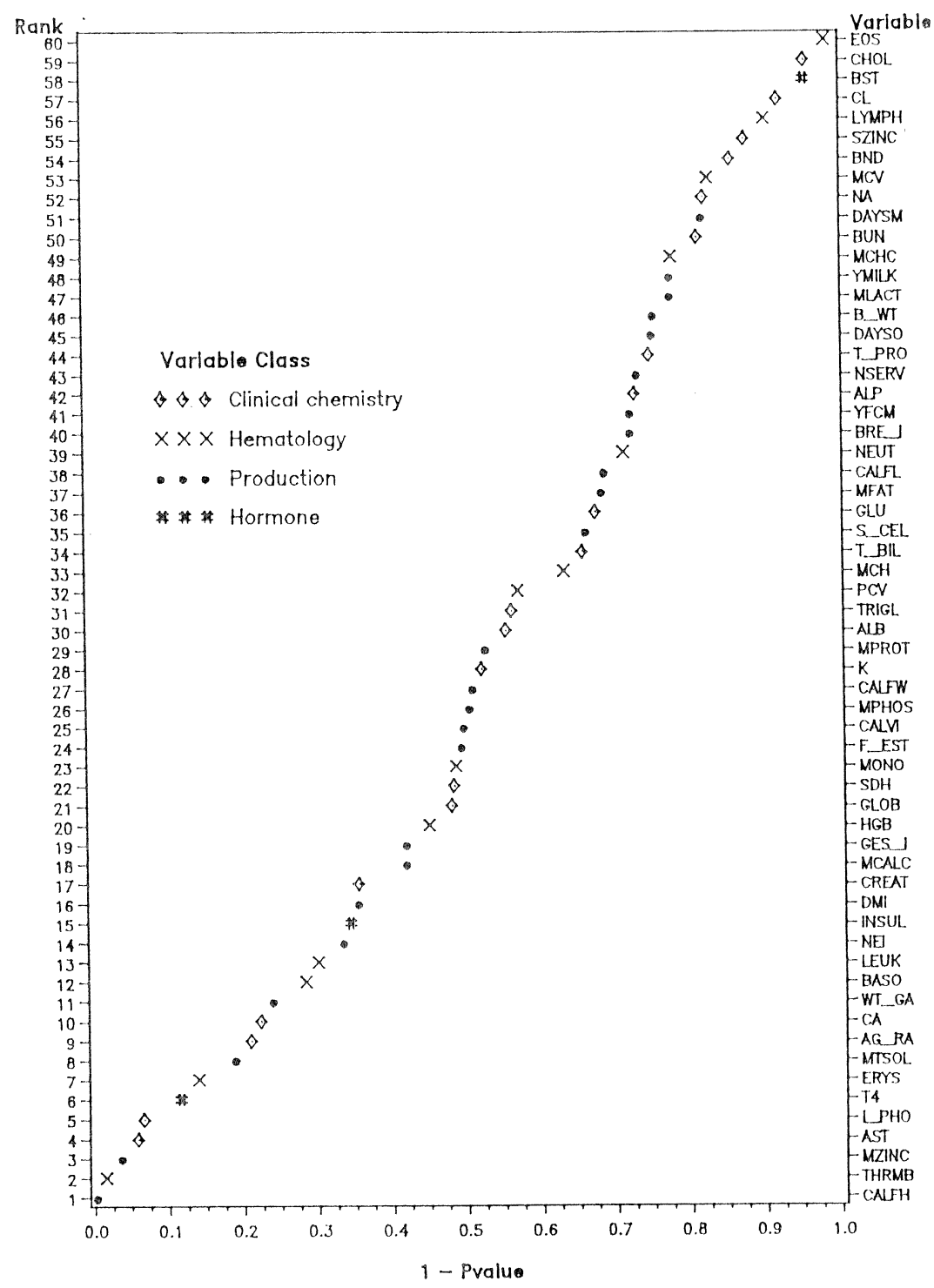

